\title{
ヒューマンファクターに基づいた海難要因分析に関する研究 〜海難分析に特化したCPCの修正〜
}

竹本孝弘 $*$ ·三友信夫** 疋田賢次郎**・吉村健志**

\section{A Study on Human Factors Analysis for Possible Factors of Marine Accident - Modifying CPC for Marine Accident Analysis-}

\author{
Takahiro TAKEMOTO, Nobuo MITOMO \\ Kenjioro HIKITA and Kenji YOSHIMURA
}

\begin{abstract}
Many marine accidents are considered to be caused by human factors. However analytical method for marine accident based on this human factors is not developed. About human factors, some methods for human reliability analysis method are proposed. CREAM (Cognitive Reliability and Error Analysis Method) is one of human reliability analysis methods. In this method, the new concept of CPC (Common performance conditions) is introduced to improve the result of analysis.

In this study, we aim to make analytical method for marine accidents based on human factors. For this purpose, the concept of CREAM was introduced. To introduce CREAM, CPC was modified to specialize the marine field, first. The modified CPC was verified by analyzing actual marine accidents.

In this paper, details of the modified CPC and verification of them is shown. The main conclusions obtained by this research are as follows.

1) CREAM which is one of the human reliability analysis techniques was applied to marine accident analysis.

2) The check sheet for conducting collision marine accident analysis using corrected CPC was created.

3) The modified CPC specialized the marine field is useful to marine accident attribution analysis based on human factors
\end{abstract}

Keywords: marine disasterst, human factors, CPC, human reliability analysis キーワード:海難、ヒューマンファクター、CPC、人間信頼性解析

\section{1.はじめに}

海難を防ぐためには、過去に発生した海難からそ の要因を分析し、それらを取り除くこと、そしてそ れらの要因が海難に結びつかない工夫を行うことが 有効である。そして、この海難要因の多くは、ヒュ 一マンファクターに起因しているといわれている。 これまでも海難におるヒューマンエラー防止のため のヒューマンファクター研究は行われており (1)(2)(3)(4)、海難防止策の構築に向けた努力がなされ てきた。しかし、IMO(国際海事機関 International
Maritime Organization)の海難調查官マニュアル 等は存在するものの、ヒューマンファクターそのも のに着目した海難要因分析は行われておらず、その 主な要因とされるヒューマンファクターに基づいた 海難要因の分析手法は確立されていない。一方他の 分野、特に原子力関係では人閒信頼性解析(HRA Human Reliability Analysis)手法としてヒューマ ンファクターの観点から、幾つかの手法が提案され ている。そこで本研究では、海難防止対策への応用 も含めた海難リスクの低減を最終的な目標とし、

* 正会員 東京海洋大学大学院海洋科学技術研究科海洋工学系(干135-8533 東京都江東区越中島 2-1-6)

** 正会員 独立行政法人 海上安全技術研究所( T181-0004 東京都三鷹市新川 6-38-1) 
HRA 手法の一つである CREAM(Cognitive Reliability and Error Analysis Method)を用いヒュ 一マンファクターに基ついた海難要因分析手法の検 討を行った。

CREAM の特徴として、人間行動がなされる状 況・環境の特徵を CPC(Common Performance Condition) という概念で評価するが、この CPC を海 難に特化したものに修正し、海難分析用チェックシ 一トとして整備した。さらにこのチェックシートを 用いて海難分析を行い、ヒューマンファクターに基 ら゙く海難分析用に修正した $\mathrm{CPC}$ の妥当性を検証し た。

\section{2. 海難要因分析手法}

\section{1 CREAM について}

HRA 手法とは、作業者の不安全行動の可能性・ 頻度とその影響を定性的・定量的に評価する手法で、 第一世代 HRA 手法は機械装置に対する信頼性解析 をヒューマンエラーに応用したものである。作業者 の認知過程は考慮せず、スキルベース、ルールベー ス行動に基づく解析を行うものである。一方、第一 世代 HRA 手法の機械的なヒューマンエラーの要素 分析の欠点を克服するために開発されたのが第二世 代 HRA 手法で、「識別」「入力情報の処理」といっ た認知過程(文脈)を考慮し、知識ベースでのエラー （確信的エラー）へも対応できるようにしたものであ る。

海難分析に用いることができる HRA 手法として は、知識ベースエラーに対応し、緊急時における組 織の意思決定過誤評価の必要性から、第二世代 HRA 手法が適当である。第二世代 HRA としては、米国 の THERP(5)やスウェーデンの $\mathrm{CREAM}^{(6)}$ 等がある。 本研究の目的が海難の要因レベルの抽出であること から、CREAM のスクリーニング手法の導入を検討 する。

CREAM は、認知的側面を積極的に取り入れた HRA 手法である。具体的には、CPC というヒュー マンファクターを表す概念を導入することにより、 人間の行動環境の定性的解析を行うとともに、評価 に閾值を設定することで定量的な評価も可能とする ものである。CPC は次に示す 9 種類が提案されてい る。

（1）組織因子(Adequacy of organization)

(2) 作業環境(Working conditions)

(3) マンマシンインターフェース(Adequacy of man machine interface and operational support)
（4）運転手順書(Availability of procedures / plans)

(5) 同時に達成する目標(Number of simultaneous goals)

（6）時間余裕(Available time)

(7) 時間帯(Time of day)

(8) 訓練 - 経験 (Adequacy of training and experience)

（9）クルー協調(Crew collaboration quality)

また、これら CPC 間には依存関係が定義されて 㧍り、依存関係のある CPC に調査対象を広げるこ とで、作業者や管理者の認知過程を含めた解析の質 を高めることができる。しかし、提案されている CREAM における CPC は海難に特化したものでな いことから、この $\mathrm{CPC}$ を海難の評価にそのまま用 いることは適当ではない。そこで、ヒューマンファ クターに基づいた海難解析手法の提案を最終的な目 的とし、まず CREAM 手法の導入のために、CPC を海難に特化したものに修正し、各 CPC を評価す る項目の抽出を行うこととした。

\section{2 重突海難分析に特化した CPC の検討}

操船者の行動決定及び操船者の行動に影響を与え る因子を $\mathrm{CPC}$ を用いて評価することで、定性的な 解析の質を高めることができる。また、 CPC 評価項 目をわかりやすく表現することで、操船者行動にお ける CPCの影響をHRAの専門家でなくても取り扱， うことが可能となる。さらに CPC を海難分析に利 用すれば、専門家でなくても海難原因の特定、関連 要因の洗い出しが「機械的」に実施でき、海難分析 の質と均質化の向上が図られ、その結果、効率的・ 効果的で妥当な海難防止策を構築できる。

そこで本研究では海難分析に特化した CPC を構 築するために、まず、海難で最も発生件数の多い衝 突海難を分析対象とした CPC を検討した。

\section{3 衝突海難における操船者のヒューマン ファクター}

操船者のヒューマンエラー(操船者エラー)は Rasmussen らの提唱した人的エラーの発生過程(7) と同樣の過程に基づいて発生している。すなわち衝 突海難は操船者エラーのきっか外に始まり、操船者 の情報処理システムに様々な外部環境が作用してエ ラーが発生し、最終的に操船者が適切な操船を行わ ずに衝突に至ると考えられる。操船者エラーの発生 過程と操船者のヒューマンファクターの関係を Fig. 1 に示す。操船者エラーは「操船者エラーをもたら 


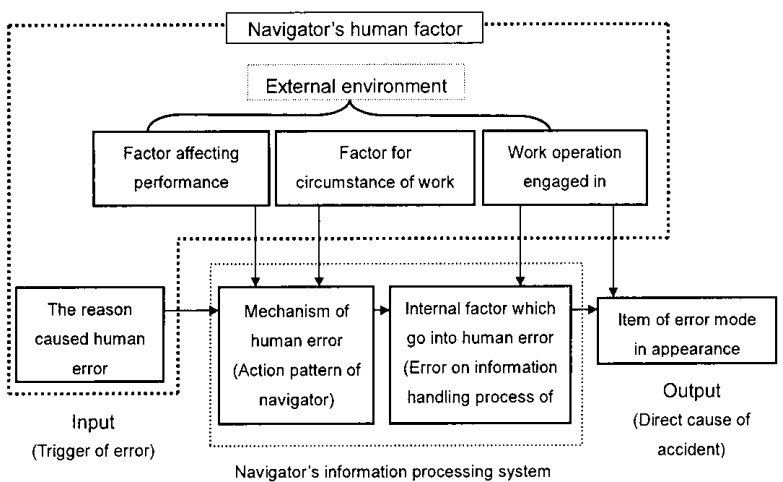

Fig. 1 Navigator's human factor

した原因」すなわち「操船者エラーのきつかけ」が ヒューマンファクターとして直接的に操船者の情報 処理システムに作用し、加えて「操船者のパフォー マンスに影響する因子」や「作業状況の因子」、「従 事していた作業」といった「外部環境」がヒューマ ンファクターとして間接的に作用することで、最終 的に衝突海難に至った操船者エラーが発生すると表 現できる(8)。

「操船者エラーをもたらした原因」はヒューマンフ アクターとして操船者の情報処理システムに直接作 用するもので、その項目は次のとおりである。

（1）外的なことがら

・システム機器による混乱

・他の人、第 3 船による混乱

・他の作業(漁ろう等)

（2）特定の状況における操船

・風潮流による圧流

・視界不良

・夜間

・船舶交通の輻輳

・特殊な操縦性能

- その他

（3）操船者が能力を損なっている

- 病気

- 怪我

・その他

(4) 非外的なことがら

- 無意識の行動

- 意識的行動

- 破壊的行為

（5）上記以外、分類不能

「操船者のパフォーマンスに影響する因子」はヒュ 一マンファタターとして間接的に操船者の情報処 理システムに作用するもので、その項目は次のと
おりである。

（1）主観的目標と概念

・過大な要求

・競合する目標

（2）知的負荷 - 設備

・不適切な作業空間

- 並列作業

・不適切な教育

・不適切な訓練と手引書

- その他

（3）感情的因子

- 社会的因子

・不十分な負荷と倦总

- 時間的切迫感

- 失敗の恐怖

- その他

これらの項目に加えて管理者の安全管理体制を提 案されている $9 つ の \mathrm{CPC}$ に分類すると共に、各 $\mathrm{CPC}$ を衝突海難分析に適当な名称に変更し、さらにこれ までの衝突海難の分析から重要性が指摘されている コミュニケーションを CPCの一つとして追加して、 衝突海難分析に特化した CPCに修正した。

\section{4 衝突海難分析用 CPC}

衝突海難分析用に修正した CPC と各評価項目及 び細目は次のとおりである。

（1）安全管理体制の妥当性

・教育訓練内容の妥当性

船種、操縦性能、航行海域、航行環境、搭載し ている航海計器、ヒューマンファクター、特殊な 操縦性能

・教育訓練体制の妥当性

教育形態、インストラクターの資質、実施間隔、 実施時期

- 当直管理体制の妥当性

労務管理、運航管理、管理者の能力

- 外部加らの支援・連絡体制の妥当性

情報支援、情報伝達・受取能力、VTS、エスコ 一トボート、タグボート、水先人

（2）航行当直環境

- 操船に影響する航行環境

風潮流、水深、可航幅、視界、夜間、船舶輻輳 - 自船の操縦性能

全長、全幅、喫水、トリム、風左面積、針路安 定性、追従性能、旋回性能、停止性能 
・他船の操縦性能

全長、全幅、喫水、風圧面積、旋回性能、停止 性能

- 船橋の当直環境

当直人数と職務、照明、騒音、温度、死角、設 備の配置

（3）マンマシンインターフェース

・航海当直に影響する船橋装置の故障

双眼鏡、コンパス、レーダ、ARPA、ECDIS、

AIS、VHF、汽笛、航海灯、操舵装置、オートパ イロット、舵角指示器、エンジンテレグラフ、速 力計、主機、主機回転数計、スラスター、船内電 話、ワイパー、船橋空調、船橋照明

・航海当直に影響する船橋装置へのアクセス性 双眼鏡、コンパス、レーダ、ARPA、ECDIS、 AIS、VHF、汽笛制御盤、航海灯制御盤、操舵装 置、オートパイロット、舵角指示器、エンジンテ レグラフ、速力計、主機回転数計、スラスター制 御盤、船内電話

・航海当直に影響する航海機器のヒューマンエラー 防止への配慮

コンパス、レーダ、ARPA、ECDIS、AIS、VHF、 汽笛制御盤、オートパイロット、舵角指示器、工 ンジンテレグラフ、主機回転数計、スラスター制 御盤、船内電話

（4）操船マニュアルの妥当性

・指揮命令系統

指揮命令系統

- 判断基準

避航基淮

- 航行環境

航行環境变化一の対応

・ヒューマンファクター

ヒューマンエラー対策の考慮

・用語・表現

用語・表現の整合性

・マニュアル構成

該当部分へのアクセス性

（5）同時に達成する目標数

- 航行海域

航路航行、港湾航行、可航水域の制限、視界に よる制限

・船舶輻輳

漁船群（航行中・操業中）、船舶集中、海域の 輻輳度

・他の作業

安全航行のための補助作業、操船者自身の作業、
漁労（自船）、その他の作業

（6）時間余裕

- 航行海域

航路航行、港湾航行、可航水域の制限、視界に よる制限

・船舶輻輳

漁船群（航行中・操業中）、船舶集中、海域の 輻輳度

・他の作業

安全航行のための補助作業、操船者自身の作業、 漁労 (自船)、その他の作業

（7）時間帯

- 航行時間带

航行時間帯、操船者のコンディション

（8）操船者のリソース

- 操船者の知識

船種、操縦性能、航行海域、航行環境、搭載し ている航海計器、ヒューマンファクター、特殊な 操縦性能

・操船者の経験

免許の種類・資格、乗船経験(当直経験)

・操船者の能力

体調、安全に対する意識レベル、航海当直のモ ラル

（9）コミュニケーションと情報の共有

・船内コミュニケーションと情報の共有

船橋内、船長当直者間、船橋と機関室、SMS マニュアル、船長命令簿、引継ぎメモ (当直者間)、 口頭による伝達事項

・他船とのコミュニケーションと情報の共有

汽笛、VHF、AIS、灯火・形象物（国際信号旗 含む)、昼閒信号灯、これらの確認

・处部からの支援コミュニケーションと情報の共有 エスコートボート・タグ、VTS

\section{3. 修正 CPC の検証}

修正した CPC の妥当性を検証するため、海難審 判裁決及び運輸安全委員会の船舶事故調査報告書か ら得た海難に関する情報を利用して、海難要因分析 を行った。要因分析は誰が行っても同樣の結果とな ることが重要となるため、修正された $\mathrm{CPC}$ 利用の ためのチェックシートを作成し、評価者は、これを 用いて海難要因分析を行った。前述したように要因 分析は誰が行っても同様の結果となることが重要で あると考え、評伍者は船舶運航未経験者とし、専門 家のアドバイスのもとに評価を実施した。 
Table 1 Selected Collision accident and type

\begin{tabular}{c|c|l}
\hline \multicolumn{2}{|c|}{ Collision accidents } & \multicolumn{2}{c}{ Type of accidents } \\
\hline 1 & $\begin{array}{r}\text { Collision of tanker Ocean Phoenix } \\
\text { cargo ship Daigo Eiseimaru } \\
\text { and cargo ship Gold Leader }\end{array}$ & $\begin{array}{l}\text { Entrance of fairway } \\
\text { Crowded with ships }\end{array}$ \\
\hline 2 & $\begin{array}{c}\text { Collision of cargo ship HARMONY WISH } \\
\text { and cargo ship Shinkazuryu }\end{array}$ & $\begin{array}{l}\text { Landlocked bay } \\
\text { Poor visibility condition } \\
\text { Navigation of recommended fairway }\end{array}$ \\
\hline 3 & $\begin{array}{r}\text { Collision of cargo ship Tohkohmaru } \\
\text { and Machirude }\end{array}$ & $\begin{array}{l}\text { Night } \\
\text { Pilot on board } \\
\text { Immediately after the change of watch }\end{array}$ \\
\hline 4 & $\begin{array}{r}\text { Collision of cargo ship NORD POWER } \\
\text { and cargo ship HAI YING }\end{array}$ & $\begin{array}{l}\text { Narrow channel } \\
\text { Crowded with ships } \\
\text { Two pilots on board }\end{array}$ \\
\hline 5 & $\begin{array}{r}\text { Collision of chemical tanker SAMHO HERON } \\
\text { and cargo ship GOLDEN WING }\end{array}$ & $\begin{array}{l}\text { Landlocked bay } \\
\text { Night } \\
\text { Navigation of recommended fairway } \\
\text { Foreign ships each other }\end{array}$ \\
\hline
\end{tabular}

\begin{tabular}{|c|c|c|c|c|c|}
\hline \multirow{3}{*}{\begin{tabular}{|c}
$\begin{array}{c}\text { Adequacy of safety } \\
\text { management system }\end{array}$ \\
$\begin{array}{c}\text { Navigation condition, } \\
\text { Watch condition }\end{array}$ \\
\end{tabular}} & \multicolumn{3}{|c|}{$\begin{array}{l}\text { Analysis Result } \\
\text { Standard }\end{array}$} & \multicolumn{2}{|c|}{ Bad } \\
\hline & \multirow{2}{*}{$\begin{array}{l}\text { Very efficient } \\
\text { Advantageous }\end{array}$} & \multicolumn{2}{|c|}{ Efficient } & Inefficient & Deficient \\
\hline & & Compatible & $\begin{array}{c}\text { Less } \\
\text { compatible }\end{array}$ & \multicolumn{2}{|c|}{ Incompatible } \\
\hline $\begin{array}{c}\text { MMl Adequacy of Man- } \\
\text { Machine interface }\end{array}$ & Supportive & Adequate & Tolerable & \multicolumn{2}{|c|}{ Inappropriate } \\
\hline $\begin{array}{c}\text { Adequacy of navigation } \\
\text { manuals }\end{array}$ & Appropriate & \multicolumn{2}{|c|}{ Acceptable } & \multicolumn{2}{|c|}{ Inappropriate } \\
\hline Number of goals & $\begin{array}{c}\text { Fewer than } \\
\text { capacity }\end{array}$ & \multicolumn{2}{|c|}{$\begin{array}{l}\text { Matching current } \\
\text { capacity }\end{array}$} & \multicolumn{2}{|c|}{ More than capacity } \\
\hline Available time & Adequate & \multicolumn{2}{|c|}{ Temporarily inadequate } & \multicolumn{2}{|c|}{ Continuously inadequate } \\
\hline Time of day & & \multicolumn{2}{|c|}{ Day-time } & \multicolumn{2}{|c|}{ Night time } \\
\hline Resources of navigators & $\begin{array}{l}\text { Adequate, high } \\
\text { experience }\end{array}$ & \multicolumn{2}{|c|}{$\begin{array}{l}\text { Adequate, limited } \\
\text { experience }\end{array}$} & \multicolumn{2}{|c|}{ Inadequate } \\
\hline $\begin{array}{l}\text { Communication and } \\
\text { information-sharing }\end{array}$ & Very efficient & \multicolumn{2}{|c|}{ Efficient } & Inefficient & Deficient \\
\hline
\end{tabular}

Fig. 2 The modified CPC evaluation matrix

本研究の目的から Table 1 に示寸様々なタイプの 衝突海難を選択した。選択された海難の報告書（海 難審判裁決及び運輸安全委員会の船舶事故調査報告 書）にある考察、所見等といった部分には調查機関 が決定した海難の要因が含まれていることから、評 価者はこれらの情報には触れずに事実の経過情報の みに基づいて要因分析を行った。

検証作業と並行して、必要に応じて、チェックシ 一トに項目の追加、項目の表現の修正等を行うと共 に、CPC も再度、修正した。今回の検証作業の結果、 衝突海難分析用に修正された CPC 評価マトリック スをFig. 2 に示す。CPC 評価マトリックスは各 CPC と CPC の各評価項目に設定した「ある・なし」、「適 切・不適切」、「優秀・適切・不十分」といった閾值 を用いた評価結果を「良い」「標準」「悪い」で表現 している。

検証作業による評価は、各衝突船舶に関わるヒュ ーマンファクターが $\mathrm{CPC}$ の項目ごとに用意された どのチェック項目に該当するかついて評価を行った。 さらに、閾值を用いてこれらの結果が $\mathrm{CPC}$ 評価マ トリックスのどの状態に該当するかについて調査し、

\begin{tabular}{|c|c|c|c|c|c|}
\hline \multirow{3}{*}{$\begin{array}{c}\text { Adequacy of safety } \\
\text { management system } \\
\text { Navigation condition, } \\
\text { Watch condition }\end{array}$} & \multicolumn{3}{|c|}{$\begin{array}{c}\text { Analysis Result } \\
\text { Standard }\end{array}$} & \multicolumn{2}{|c|}{ Bad } \\
\hline & 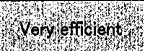 & \multicolumn{2}{|c|}{ Efficient } & Inefficient & Deficient \\
\hline & Advantageous & Compatible & $\begin{array}{c}\text { Less } \\
\text { compatible }\end{array}$ & \multicolumn{2}{|c|}{$\begin{array}{l}1 \\
7\end{array}$} \\
\hline $\begin{array}{l}\text { MMI Adequacy of Man- } \\
\text { Machine interface }\end{array}$ & Supportive & Adequate & Tolerable & \multicolumn{2}{|c|}{ Inappropriate } \\
\hline $\begin{array}{l}\text { Adequacy of navigation } \\
\text { manuals }\end{array}$ & Appropriate & \multicolumn{2}{|c|}{ 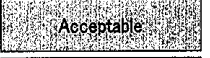 } & \multicolumn{2}{|c|}{ Inappropriate } \\
\hline Number of goals & $\begin{array}{l}\text { Fewer than } \\
\text { capacity }\end{array}$ & \multicolumn{2}{|c|}{ 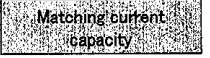 } & \multicolumn{2}{|c|}{ More than capacity } \\
\hline Available time & Adequate & \multicolumn{2}{|c|}{ Temporarily inadequate } & \multicolumn{2}{|c|}{ Continuously inadequate } \\
\hline Time of day & & \multicolumn{2}{|c|}{ Why } & \multicolumn{2}{|c|}{ Night time } \\
\hline Resources of navigators & $\begin{array}{l}\text { Adequate, high } \\
\text { experience }\end{array}$ & \multicolumn{2}{|c|}{$\begin{array}{l}\text { Adequate, limited } \\
\text { experience }\end{array}$} & \multicolumn{2}{|c|}{ 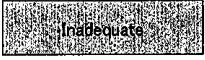 } \\
\hline $\begin{array}{l}\text { Communication and } \\
\text { information-sharing }\end{array}$ & Very efficient & \multicolumn{2}{|c|}{ Efficient } & Inefficient & be fif \\
\hline
\end{tabular}

Fig. 3 CPC analytical result(NORD POWER)

\begin{tabular}{|c|c|c|c|c|c|}
\hline \multirow{3}{*}{$\begin{array}{c}\text { Adequacy of safety } \\
\text { management system } \\
\text { Navigation condition, } \\
\text { Watch condition }\end{array}$} & \multicolumn{2}{|c|}{ Analysis Result } & $\begin{array}{l}\text { Result } \\
\text { lard }\end{array}$ & \multicolumn{2}{|c|}{$\mathrm{Bad}$} \\
\hline & \multirow{2}{*}{$\begin{array}{c}\text { Good } \\
\text { Very efficient } \\
\text { Advantageous }\end{array}$} & \multicolumn{2}{|c|}{ 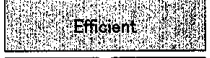 } & Inefficient & Deficient \\
\hline & & Compatible & \begin{tabular}{|c|} 
Less \\
compatible \\
\end{tabular} & \multicolumn{2}{|c|}{ Incompatible } \\
\hline $\begin{array}{l}\text { MMI Adequacy of Man- } \\
\text { Machine interface }\end{array}$ & Supportive & Adequate & Tolerable & \multicolumn{2}{|c|}{ Inappropriate } \\
\hline $\begin{array}{l}\text { Adequacy of navigation } \\
\text { manuals }\end{array}$ & Appropriate & \multicolumn{2}{|c|}{ M } & \multicolumn{2}{|c|}{ Inappropriate } \\
\hline Number of goals & $\begin{array}{c}\text { Fewer than } \\
\text { capacity }\end{array}$ & \multicolumn{2}{|c|}{\begin{tabular}{|c|} 
Matching current \\
capacity
\end{tabular}} & \multicolumn{2}{|c|}{ More than capacity } \\
\hline Available time & Adequate & \multicolumn{2}{|c|}{ Yor } & \multicolumn{2}{|c|}{ Continuously inadequate } \\
\hline Time of day & & \multicolumn{2}{|c|}{ Hork } & \multicolumn{2}{|c|}{ Night time } \\
\hline Resources of navigators & $\begin{array}{c}\text { Adequate, high } \\
\text { experience }\end{array}$ & \multicolumn{2}{|c|}{$\begin{array}{c}\text { Adequate, limited } \\
\text { experience }\end{array}$} & \multicolumn{2}{|c|}{ 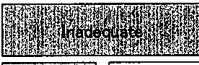 } \\
\hline $\begin{array}{l}\text { Communication and } \\
\text { information-sharing }\end{array}$ & Very efficient & \multicolumn{2}{|c|}{ Efficient } & 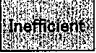 & Deficient \\
\hline
\end{tabular}

Fig. 4 CPC analytical result (HAI YING)

「悪い」状態とされたチェック項目の数に基づき主 観的な評価を行った。CPC 評価の解析結果例につい て、Fig.3 及び Fig. 4 に示す。CPC 評価マトリック スは CPC 各評価項目が海難に及ぼす影響を表現し ており、海難を引き起こしたヒューマンファクター を定性的に評価できるとともに、閾值を設定するこ とで定量值に換算できることもわかった。

\section{4. 考察}

それぞれの海難について CPC チェックシートか ら得られた要因を Table 2 に示す。これらの結果は、 いずれも各事故報告書等にある海難の要因とされる ものとほぼ一致しており、今回作成した CPC 及び チェックシートによる海難の要因分析は妥当性のあ るものと考えられる。また、作成した衝突海難分析 用の CPC は船舶間の衝突に限らず、乗揚げや単独 衝突用に修正することで、広範囲に応用できる内容 となっていることも確認できた。一方で、事故報告 書等に該当項目に関する情報が存在しない場合には、 その項目が評価できないという問題もあることがわ かった。 
Table 2 Factor of marine accidents obtained from analyses

\begin{tabular}{|c|c|c|c|c|c|c|c|c|c|c|c|}
\hline & \multicolumn{3}{|c|}{ Accident 1} & \multicolumn{2}{|c|}{ Accident 2} & \multicolumn{2}{|c|}{ Accident 3} & \multicolumn{2}{|c|}{ Accident 4} & \multicolumn{2}{|c|}{ Accident 5} \\
\hline & \begin{tabular}{|c|} 
Ocean \\
Phoenix \\
\end{tabular} & Daigo Eisei & Gold Reader & $\begin{array}{c}\text { HARMONY } \\
\text { WISH }\end{array}$ & $\begin{array}{c}\text { Shin } \\
\text { Kazuryu }\end{array}$ & $\begin{array}{c}\text { Toukou } \\
\text { Maru }\end{array}$ & Machirude & $\begin{array}{c}\text { NORD } \\
\text { POWER } \\
\end{array}$ & HAI YING & $\begin{array}{l}\text { SAMHO } \\
\text { HERON } \\
\end{array}$ & $\begin{array}{c}\text { GOLDEN } \\
\text { WING }\end{array}$ \\
\hline $\begin{array}{l}\text { Adequacy of safety } \\
\text { management system }\end{array}$ & $\begin{array}{l}\text { insufficient } \\
\text { lookout }\end{array}$ & $\begin{array}{l}\text { insufficient } \\
\text { lookout }\end{array}$ & $\begin{array}{l}\text { insufficient } \\
\text { lookout, } \\
\text { insufficient } \\
\text { navigation } \\
\text { order of } \\
\text { captain } \\
\end{array}$ & $\begin{array}{l}\text { restricted } \\
\text { visivility }\end{array}$ & $\begin{array}{l}\text { restricted } \\
\text { visivility }\end{array}$ & & & & & & \\
\hline $\begin{array}{l}\text { Navigation condition, } \\
\text { Watch condition }\end{array}$ & & dereliction & $\begin{array}{l}\text { insufficient } \\
\text { number of } \\
\text { watch } \\
\text { people, } \\
\text { dereliction }\end{array}$ & $\begin{array}{l}\text { restricted } \\
\text { visivility }\end{array}$ & $\begin{array}{l}\text { restricted } \\
\text { visivility }\end{array}$ & $\begin{array}{l}\text { night time. } \\
\text { crowded } \\
\text { with ships. }\end{array}$ & $\begin{array}{l}\text { night time, } \\
\text { crowded } \\
\text { with ships. }\end{array}$ & $\begin{array}{l}\text { crowded } \\
\text { with ships }\end{array}$ & $\begin{array}{l}\text { crowded } \\
\text { with ships }\end{array}$ & & \\
\hline $\begin{array}{l}\text { MMI Adequacy of Man- } \\
\text { Machine interface }\end{array}$ & & & & & & & & & & & \\
\hline $\begin{array}{c}\text { Adequacy of navigation } \\
\text { manuals }\end{array}$ & & & & & & & & & & & \\
\hline Number of goals & & other tasks & & $\begin{array}{l}\text { restricted } \\
\text { visivility }\end{array}$ & $\begin{array}{l}\text { restricted } \\
\text { visivility }\end{array}$ & & other tasks & & & & $\begin{array}{l}\text { exist of } \\
\text { other ship }\end{array}$ \\
\hline Available time & & & & $\begin{array}{l}\text { restricted } \\
\text { visivility }\end{array}$ & $\begin{array}{l}\text { restricted } \\
\text { visivility }\end{array}$ & $\begin{array}{l}\text { night time, } \\
\text { crowded } \\
\text { with ships }\end{array}$ & & & & & \\
\hline Time of day & & & & & & night time & night time & & & & \\
\hline $\begin{array}{l}\text { Resources of } \\
\text { navigators }\end{array}$ & & & & $\begin{array}{l}\text { restricted } \\
\text { visivility }\end{array}$ & $\begin{array}{l}\text { restricted } \\
\text { visivility }\end{array}$ & $\begin{array}{l}\text { lack of } \\
\text { moral } \\
\text { (insufficient } \\
\text { lookout of } \\
\text { movement). }\end{array}$ & & \begin{tabular}{|l|} 
lack of \\
moral(hesita \\
ting \\
between \\
pilots)
\end{tabular} & $\begin{array}{l}\text { didn't know } \\
\text { the } \\
\text { navigational } \\
\text { area, }\end{array}$ & \begin{tabular}{|l|} 
in bad \\
condition, \\
lack of \\
moral \\
(insufficient \\
lookout.) \\
\end{tabular} & $\begin{array}{l}\text { lack of } \\
\text { moral } \\
\text { (insufficient } \\
\text { lookout) }\end{array}$ \\
\hline $\begin{array}{l}\text { Communication and } \\
\text { information-sharing }\end{array}$ & $\begin{array}{l}\text { insufficient } \\
\text { communicati } \\
\text { on inboard } \\
\text { and other } \\
\text { ships }\end{array}$ & $\begin{array}{l}\text { insufficient } \\
\text { communicati } \\
\text { on inboard } \\
\text { and other } \\
\text { ships }\end{array}$ & 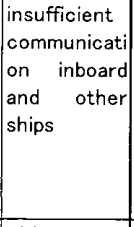 & $\begin{array}{l}\text { without } \\
\text { using fog } \\
\text { signals and } \\
\text { whistles }\end{array}$ & $\mid \begin{array}{l}\text { without } \\
\text { using fog } \\
\text { signals and } \\
\text { whistles }\end{array}$ & $\begin{array}{l}\text { misidentifyin } \\
\text { g lights }\end{array}$ & $\begin{array}{l}\text { position of } \\
\text { lights }\end{array}$ & $\begin{array}{l}\text { insufficient } \\
\text { information- } \\
\text { sharing } \\
\text { inboard } \\
\text { including } \\
\text { captain }\end{array}$ & $\begin{array}{l}\text { without } \\
\text { confirmation } \\
\text { of VHF } \\
\\
\end{array}$ & $\begin{array}{l}\text { insufficient } \\
\text { information } \\
\text {-sharing } \\
\text { inboard, } \\
\text { without } \\
\text { using a } \\
\text { whistle and } \\
\text { VHF } \\
\end{array}$ & $\begin{array}{l}\text { without } \\
\text { using VHF }\end{array}$ \\
\hline $\begin{array}{l}\text { Factors from } \\
\text { accidents reports }\end{array}$ & $\begin{array}{l}\text { without } \\
\text { using } \\
\text { reminder } \\
\text { signal, } \\
\text { insufficient } \\
\text { lookout. } \\
\text { insufficient } \\
\text { navigation } \\
\text { order of } \\
\text { captain }\end{array}$ & \begin{tabular}{|l} 
insufficient \\
lookout, \\
other tasks, \\
in sufficient \\
safety \\
education \\
(select of \\
course). \\
insufficient \\
safety \\
management \\
system
\end{tabular} & $\begin{array}{l}\text { without } \\
\text { using } \\
\text { reminder } \\
\text { signals and } \\
\text { caution } \\
\text { signal to } \\
\text { other ships, } \\
\text { insufficient } \\
\text { lookout, } \\
\text { insufficient } \\
\text { navigation } \\
\text { order of } \\
\text { captain }\end{array}$ & $\begin{array}{l}\text { Judgment } \\
\text { with only } \\
\text { radar under } \\
\text { restricted } \\
\text { visibility by } \\
\text { fogs }\end{array}$ & $\begin{array}{l}\text { Judgment } \\
\text { with only } \\
\text { radar under } \\
\text { restricted } \\
\text { visibility by } \\
\text { fogs }\end{array}$ & \begin{tabular}{|l|} 
Captain \\
didn't \\
navigate, \\
violation of \\
navigational \\
area \\
insufficient \\
lookout of \\
movement(w \\
ithout \\
confirmation \\
by radar, \\
without \\
confirmation \\
of lights. \\
etc.)
\end{tabular} & \begin{tabular}{|l|} 
position of \\
lights, other \\
tasks
\end{tabular} & \begin{tabular}{|l|} 
lack of \\
navigation \\
order of \\
captain, \\
wrong \\
assumption \\
that \\
HAIYING \\
accept the \\
order from \\
NORD \\
POWER, \\
insufficient \\
information \\
-sharing \\
with pilots \\
and in board \\
\end{tabular} & $\begin{array}{l}\text { wrong } \\
\text { assumption } \\
\text { that NORD } \\
\text { POWER will } \\
\text { turn aside }\end{array}$ & $\begin{array}{l}\text { in bad } \\
\text { condition, } \\
\text { insufficient } \\
\text { lookout by } \\
\text { wrong } \\
\text { assumption }\end{array}$ & $\begin{array}{l}\text { insufficient } \\
\text { lookout by } \\
\text { wrong } \\
\text { assumption, } \\
\text { exist of } \\
\text { other ship }\end{array}$ \\
\hline
\end{tabular}

今後は、CPCの精査とチェックシートの修正・追 加等を行うとともに $\mathrm{CPC}$ 間の依存関係を解明し、 操船者及び管理者の認知行動及び内的要因を含めた 検討を行い、分析手法を確立寸る必要がある。

\section{5. 結論}

本研究では、海難防止対策への応用も含めた海難 リスクの低減を最終的な目標とし、CREAM の CPC 概念を海難分析に特化した形に修正し、ヒューマン ファクターに基づいた海難要因分析手法の検討を行 った。得られた主要な結論は次のとおりである。

(1) HRA 手法の一つである CREAM は海難分析に応 用可能である。

（2）CREAM の特徵である CPC 及び各評価項目を、 操船者及び管理者のヒューマンファクターに基
づいて海難分析に特化したものに修正した。

（3）修正した CPC を用いて衝突海難分析を行うた めのチェックシートを作成した。

（4）チェックシートにより海難分析を行い、CPCを 用いてヒューマンファクターに基づく海難要因 分析が可能であることを確認した。

（5）チェックシートを使用することで要因分析の質 を高めるとともに均質化が図られた。

（6）事故報告書等の海難要因と海難分析用 CPCによ り導き出した要因を比較することで、今回提案し た分析手法の妥当性を検証した。

(7) 衝突海難分析用 CPC は衝突以外の海難にも適用 可能である。

（8）今後、各 CPC 評洒項目の精査を行うと共に、 
$\mathrm{CPC}$ 間の依存関倸解明し、操船者及び管理者の 認知行動及び内的要因を含めた検討を行い、 CPC を用いたチェックシートをツールとしたヒ ューマンファクターに基づく海難要因分析手法 を確立する必要がある。

（9）ヒューマンファクターが関与した海難の防止対 策を検討寸る上で、海難における各 $\mathrm{CPC}$ 評価項 目の影響を定量的に把握するため、各項目の閾值 を適切に設定する必要がある。

\section{参考文献}

(1) 遠藤真：船舶操船者のエラー発生の要因及び確 率とその定量的安全性評価について, 文部省科 学研究費補助金研究成果報告書, 1993-1994.

(2) 遠藤真：船舶操船者のヒユーマンエラーのモデ ル化についてーワークロードとパフオーマンスー, 文部省科学研究費補助金研究成果報告書, 1995-1997.

（3）伊藤博子，三友信夫他：m-SHEL モデルを用い た船舶運航のヒューマンファクター分析, 日本 航海学会論文集 第 110 号, pp.83-91, 2004.3.

（4）竹本孝弘，阪本義治他：衝突海難にお忊る人的 エラーの発生形態，日本航海学会論文集 第 110 号, pp.109-116, 2004.3.

(5) S. E. Cooper, A. Ramey-Smith, et al.: A Technique for Human Error Analysis (AHTEANA), NUREG/CR-6350, US-NRC. 、 1996.

(6) E. Hollnagel : Cognitive reliability and error analysis method - CREAM, Elsevier, Oxford, UK, 1998.

(7) Rasmussen, J., el al. :Classification System for Reporting Events Involving Human Malfunction, Riso-M-2240, 1981.

（8）竹本孝弘、岩崎裕行他：操船者の情報処理レシ ステムに基づく避航行動，日本航海学会論文集 第 120 号, pp.35-43, 2009.3.

\section{質疑応答}

佐伯公康(水産総合研究センター)：

ご発表の中にありました「CPCの依存関係定義」 について、本研究における活用がどうなっているか ご教示下さい。

竹本孝弘 :

今回の研究では CREAM の特徴である CPC を衝 㔖海難に特化したものに修正し、その妥当性を検証 しました。今後、今回作成した CPC の精査とチェ
ックシートの修正・追加等を行うとともに分析を進 め、CPC 間の依存関係を解明して操船者及び管理者 の認知行動及び内的要因を含めた検討を行う予定で す。

山田孝三郎(元日立造船)：

船の操縦性能を操船者に正確にわかりやすく与え ることが重要と考えるが、これは CPC の項目のな かでは「操船マニュアルの妥当性」に相当するのか。 竹本孝弘：

操船者が操縦性能を正確に把握しない状態に至る 状況を作り出すのは、CPC「安全管理体制の妥当性」 の細目「教育訓練の妥当性」や CPC「操船マニュア ルの妥当性」の細目「避航基準」で評価できます。

\section{伊藤耕二(川崎汽船）：}

本研究におうる「操船者」の定義とは何でしょう か。例えげ単独航海当直中の操船者、ブリッジチー 厶を形成した場合の操船者、パイロット乗船時の操 船者など、それぞれの場合における操船者は誰か、 教えて下さい。

\section{竹本孝弘：}

「操船者」とは避航法を判断し、オーダーを発令 して実際に操船する者を示しています。単独航海当 直中ではあれば当直航海士、複数でブリッジチーム を形成している場合は、チームからの情報を収集し て避航法を決定、実行する者です。ブリッジチーム に船長と当直航海士がいて、当直航海士に操船を任 せている場合は当直航海士が操船者となりますし、 船長自ら操船していれば船長が操船者となります。 パイロット乗船時、パイロットは船長に操船の助言 を行うことになっていますが、実際に避航法を決定 し、船長の了解を得てオーダーを発令しているのが パイロットであればパイロットが操船者となります。 